\title{
Paradoxical vasoconstrictive effect in the contralateral hemisphere after carotid stenting
}

Figure Perfusion CT before and after carotid stenting

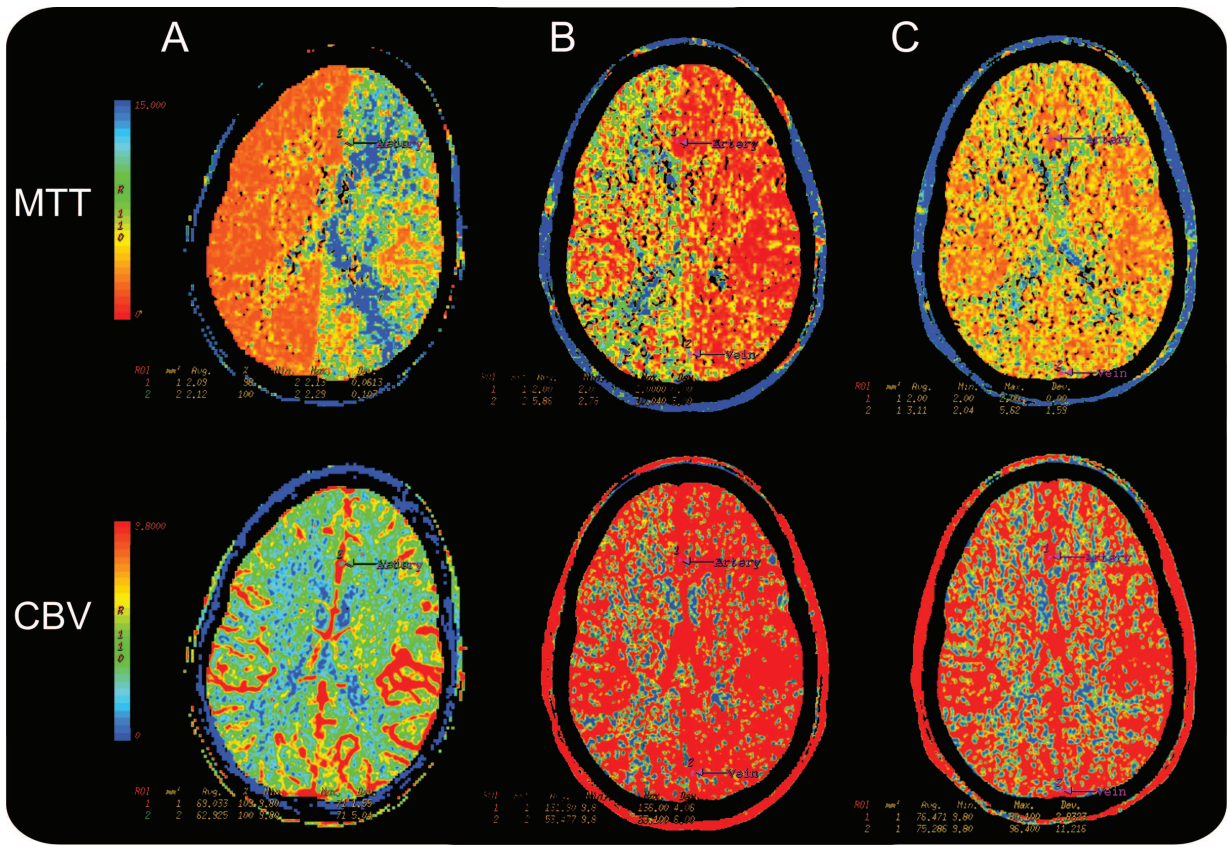

(A) Prior to carotid revascularization, the mean transit time (MTT) and cerebral blood volume values were elevated in the left hemisphere. (B) Immediately poststenting, MTT was prolonged in the right hemisphere. (C) Three days later, these findings normalized, indicating the resolution of paradoxical vasoconstrictive phenomenon in the contralateral hemisphere.

A 31-year-old woman developed aphasia and right hemiparesis from left internal carotid artery dissection, with near occlusion. Her examination results worsened despite anticoagulation; CT angiography showed the left hemisphere received blood entirely through the carotid. Perfusion CT showed prolonged mean transit time (MTT) and elevated cerebral blood volume in the ipsilateral hemisphere (figure, A) consistent with hypoperfusion and compensatory vasodilation. ${ }^{1}$ Immediately after carotid stenting, the contralateral hemisphere showed prolonged MTT (figure, B). Transcranial Doppler ultrasound showed higher pulsatility index ${ }^{2}$ in the contralateral than the ipsilateral middle cerebral artery ( 2.4 vs 1.3$)$. These findings suggest that carotid revascularization may have a paradoxical vasoconstrictive effect in the contralateral hemisphere.

Kazuma Nakagawa, MD, Wade S. Smith, MD, PhD, San Francisco, CA

Author contributions: Dr. Nakagawa: drafting/revising the manuscript, study concept or design, analysis or interpretation of data; Dr. Smith: drafting/revising the manuscript, study concept or design, analysis or interpretation of data.

Disclosure: Dr. Nakagawa has received research support from the Hawai'i Community Foundation and the American Medical Association Foundation. Dr. Smith serves on a DSMB for the Harvard Clinical Research Institute; serves as Section Editor for Stroke and on the editorial board of Neurocritical Care; and serves as a consultant for and holds stock/stock options in Concentric Medical. Address correspondence and reprint requests to Dr. Kazuma Nakagawa, Neuroscience Institute, The Queen's Medical Center, 1301 Punchbowl Street, Honolulu, HI 96813; knakagawa@queens.org

1. Hoeffner EG, Case I, Jain R, et al. Cerebral perfusion CT: technique and clinical applications. Radiology 2004;231:632-644.

2. Gosling RG, King DH. Arterial assessment by Doppler-shift ultrasound. Proc R Soc Med 1974;67:447-449. 


\section{Neurology}

\section{Paradoxical vasoconstrictive effect in the contralateral hemisphere after carotid stenting}

Kazuma Nakagawa and Wade S. Smith

Neurology 2011;77;300

DOI 10.1212/WNL.0b013e318225ab1d

\section{This information is current as of July 18, 2011}

\section{Updated Information \& Services}

References

Subspecialty Collections

Permissions \& Licensing

Reprints including high resolution figures, can be found at: http://n.neurology.org/content/77/3/300.full

This article cites 2 articles, 0 of which you can access for free at: http://n.neurology.org/content/77/3/300.full\#ref-list-1

This article, along with others on similar topics, appears in the following collection(s):

\section{All Cerebrovascular disease/Stroke}

http://n.neurology.org/cgi/collection/all_cerebrovascular_disease_strok e

Carotid artery dissection

http://n.neurology.org/cgi/collection/carotid_artery_dissection

CT

http://n.neurology.org/cgi/collection/ct

Other cerebrovascular disease/ Stroke

http://n.neurology.org/cgi/collection/other_cerebrovascular_disease_st roke

Information about reproducing this article in parts (figures,tables) or in its entirety can be found online at:

http://www.neurology.org/about/about_the_journal\#permissions

Information about ordering reprints can be found online:

http://n.neurology.org/subscribers/advertise

Neurology ${ }^{\circledR}$ is the official journal of the American Academy of Neurology. Published continuously since 1951, it is now a weekly with 48 issues per year. Copyright Copyright $@ 2011$ by AAN Enterprises, Inc.. All rights reserved. Print ISSN: 0028-3878. Online ISSN: 1526-632X.

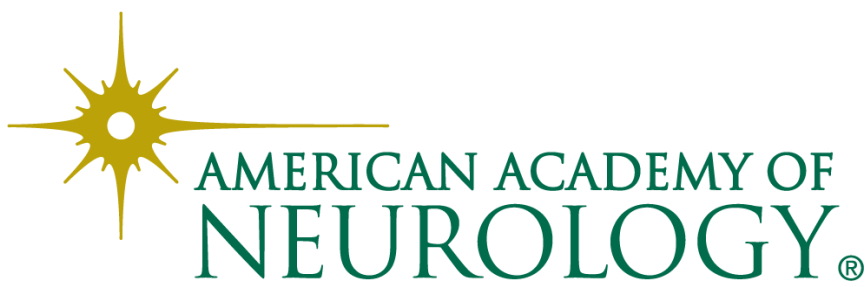

